\title{
The Melanesian Spearhead Group in terms of Indonesia's interest
}

\begin{abstract}
This qualitative study aims to encompass Indonesia's interest in seeking to join the MSG (Melanesian Spearhead Group). An in-depth interview was carried out with the Director of Directorate General of Asia, Pacific, and Africa under the Ministry of Foreign Affairs of the Republic of Indonesia aiming to obtain valid data supported by literature reviews. The findings indicate that Indonesia's attempts to join the MSG or Melanesian intergovernmental organizations basically aim to maintain domestic stability which, in this context, refers to closing down separatist movements that still exist in Indonesia, such as the FPM (Free Papua Movement), that explicitly receive international support from Melanesian countries sharing the same racial background. In an effort to preserve the country's sovereignty, Indonesia, in the era of President Joko Widodo, strives to join the MSG to prevent the Melanesian intergovernmental organization from supporting such separatist groups, which from Indonesia's perspective could disrupt the unity of the Republic of Indonesia.
\end{abstract}

Key words: Indonesia's interest, Melanesian Spearhead Group, Separatist

\section{Introduction}

$\mathrm{H}$ istorically, the close relations between Indonesia and South Pacific countries were actually established in 1984 as the issue of Irian Jaya (nowadays known as Papua) gradually emerged. This issue was triggered by the armed acts of aggression performed by the Free Papua Movement (FPM) through numerous attacks aimed at Indonesian military, civilians, and transmigration facilities in various villages in Irian Jaya.

These attacks could eventually be stopped by Indonesian military. However, this counterattack raised serious concerns in relations between Indonesia and Papua New Guinea. This was due to the fact that, when running from armed aggression to state border areas, the members of the FPM incited surrounding communities by saying that Indonesian military would conduct a counterattack upon them. This later became a trigger to the massive influx of refugees to the territory of Papua New Guinea and sparked off many refugee issues for the government of Papua New Guinea (Harris, Brown, 1985).

The government of Papua New Guinea, as a consequence, provided refugee camps for Irian Jaya people who entered the territory of Papua New Guinea; nevertheless, this led to various problems around the camps, such as violence perpetrated by some refugees upon Indonesian journalists who were reporting the refugees' condition at that time. On the other hand, the government of Papua New Guinea claimed that Indonesian Air Force had launched bomb attacks on their territory in pursuit of FPM members.

${ }^{1}$ Department of International Relations, Faculty of Social and Political Sciences, University of Muhammadiyah Malang, East Java, Indonesia. Author Correspondence, email: syaprin123@gmail. com. 
The Indonesian government in responding to this claim initiated a diplomatic and military solution to rectify the situation which was eventually resolved peacefully. Such peaceful resolution became an initial phase of close relations between Indonesia and Papua New Guinea. Even afterwards, these two countries made several agreements including the Treaty of Mutual Respect, Friendship and Cooperation, and Status of Forces Agreement (Hamid, 1996).

Studying the above phenomena, the Indonesian government finally decided to pay more attention to the South Pacific region. This was stated in the Guidelines of State Policy (GBHN) of 1983 and 1988, which disclosed that the South Pacific region was becoming an area of Indonesian foreign policy that must be specifically targeted. In the GBHN 1993, it was also asserted that collaboration among Asia-Pacific countries must be improved.

After several regime shifts, Indonesia was again surprised by the statement of the Prime Minister of one of the South Pacific countries, namely the Prime Minister of Vanuatu, Moana Carcasses Katokai Kalosil at the $25^{\text {th }}$ UN Summit for Human Rights. He delivered a speech urging the international community to support Papua Independence since the Papua people, from his perspective, had been oppressed by the Indonesian government for almost fifty years. According to him, even Pepera (Collecting Popular Opinion) in 1969 , in which a majority preferred to join Indonesia, was no more than a manipulative intrigue by the Indonesian government.

Referring to this statement, the Indonesian government eventually decided to join the MSG (Melanesian Spearhead Group) - a Melanesian intergovernmental organization. On July 2, 2015, Indonesia was finally accepted as a Permanent Member of the MSG along with Fiji, Papua New Guinea, the Solomon Archipelago, Vanuatu, and New Caledonia.

This paper primarily focuses on the aspects underlying the Indonesian policy of joining the MSG, despite the fact that this organization is rather small and consists of countries with unstable economies.

\section{Review of related literature}

\section{The Adaptive Model of Foreign Policy}

In the studies on foreign policy, a state is assumed to be a social institution in two environments. The first environment is known as the domestic (internal) environment while the second is known as the foreign (external) environment. In regard to this, when creating foreign policies a state has to adapt to both the internal and external environments, since every policy issued will surely have an impact on both (Brown, Kirsten, 2005).

Essentially, every foreign policy issued by a state appears to be a state's adaptation to both the internal and external environments. There are four possible patterns of adaptation of a state's foreign policy as a response to various issues coming from either the internal or external environment (Rosenau, 1974). First, there is preservative adaption 
as a response given by a state in reacting to demands and changes coming from both internal and external aspects. In other words, this pattern basically occurs as a result of demands and changes coming from internal and external aspects. Second, acquiescent adaptation is a response given by a state in reacting to demands and changes coming from the external environment. Third, intransigent adaptation is a response given by a state in reacting to demands and changes coming from the internal environment; and last, promotive adaptation is an absence of a state's responses in reacting to demands and changes coming from both internal and external environments.

This paper uses the preservative adaptation model to analyze the Indonesian foreign policy of joining the MSG in the era of President Joko Widodo, since it cannot be separated from the internal demand coming from the separatist movement in Indonesia which, in this case, refers to the attempts by the Free Papua Movement (FPM) to separate from the Republic of Indonesia by committing numerous acts of terror and causing insecurity in Papua. On the other hand, the external demand can be seen in the attempt of Melanesian countries, especially Vanuatu, through their Prime Ministers, to support and urge Indonesia to give independence to Papua.

\section{Methodology}

\section{Data Collecting Method}

This paper aims to establish the major reason why Indonesia strove to become an MSG member. Thus, to work out this reason, it employs a data collecting method involving an in-depth interview with the Director of the Directorate General of Asia-Pacific and Africa at the Ministry of Foreign Affairs of the Republic of Indonesia. Besides the in-depth interview, data was also collected from documentation. These two methods are important in obtaining valid data as to the reasons underlying the Indonesian government to join the MSG.

\section{Data Analysis}

The data was analyzed in the following phases:

1) the data collected by various methods, including interview, literature reviews, and so on, was read and studied rigorously in order to be used as the primary conceptual framework and to provide valid data for further study;

2) the data was further reduced and arranged systematically to grasp the main points that become the major focus in this study. This aims to promote a valid overview of the phenomena observed;

3) the reduced data was arranged in categories, to determine or define each unit or category. Each category was subsequently coded to be easily controlled and used at any time, and hence can be referred to as a basic framework to make data analysis easier. 


\section{Findings}

\section{FPM Separatist Movement in Indonesia}

A separatist movement can be defined as "political self-expression" performed by a group with particular characteristics in a specific territory (Horowitz, 1981). In regard to this, the Free Papua Movement can be categorized as a separatist movement, as its members consistently express their desire to separate from the Republic of Indonesia either through soft or hard actions.

In terms of soft action, the Free Papua Movement has persuaded the Papuan people to hate the Indonesian central government. They argue that the central government has demonstrated various discriminative actions towards Papua people, for instance: using Papua as a Military Operations Area (MOA), giving ownership of Freeport to foreigners so that it is not beneficial for the Papuan people, and so on. These attempts to influence the Papuan people have ultimately been successful in increasing the number of FPM sympathizers and triggering almost all Papuan people to think negatively about the Indonesian central government (Raweyai, Suprantio, 2002).

Meanwhile, in terms of hard action, the Free Papua Movement, along with their sympathizers, have engaged in various acts of military aggression, through attacks against the security forces and public facilities in Papua. If we refer to news stories in the mass media, there is an attack by the Free Papua Movement reported every year. For example, on January 7, 2014, the Free Papua Movement was reported to have shot a Susi Air aircraft that was carrying foods from Nabire. Further, on January 9, 2014, there was an act of armed aggression by the Free Papua Movement aimed at the office of Indonesian National Armed Forces (TNI-Polri) in East Tanggul. In the same month, on January 18, 2014, the Kompas Office, under the Military District Commands 1714/PJ in Lama Mulia City, the District of Puncak Jaya, was attacked by the Free Papua Movement (Lita, 2017).

Such aggressive actions carried out by the Free Papua Movement cannot be separated from their goal of achieving Papuan independence from the Indonesian government and of establishing an independent and sovereign state (Tebay, 2005). From the author's point of view, this seems plausible since they are never treated fairly in the distribution of resources. Another thing is that Indonesia has adopted the wrong approach (using the military) since the beginning, when the Indonesian government considered Papua as one of the Indonesian provinces.

Those aggressive actions carried out by the Free Papua Movement, in the internal context, can be categorized as separatist attempts that threaten Indonesian sovereignty. Nevertheless, such actions, in their opinion, have not yet sufficed and therefore they seek support from other countries, especially countries populated mainly by people of same race, which in this case are the Melanesian countries. ${ }^{2}$

2 Etymologically, "Melanesian" comes from two words "melas" or "mela" which means black, and "nesos" or "nesoi" which means archipelago. Generally, Melanesian community is characterized as a community with dark skin complexion and curly hair (Wardhani, 2015a). 
The Free Papua Movement in Seeking Support

from the Melanesian Spearhead Group

As mentioned in the previous section, the FPM's attempts to secede from Indonesia cannot be detached from their main goal of establishing an independent state, and one of requirements for this independence, in terms of international law, is the acknowledgement by other countries. Realizing such a requirement, the Free Papua Movement attempts to seek support from other countries, especially those in the South Pacific region. This is understandable, since the Free Papua Movement feels a racial kinship with Melanesian countries.

The initial step taken by the Free Papua Movement was applying for membership of the Melanesian Spearhead Group (MSG), which is a South Pacific regional organization established in Port Vila on March 14, 1988, by the heads of governments of Melanesian countries such as Papua New Guinea, Vanuatu, and Solomon Island (Wardhani, 2015b). This application for membership can be interpreted as the FPM's attempt to seek support from the Melanesian Spearhead Group.

The membership application by the FPM was submitted by the biggest organization affiliated under the FPM banner, which is the West Papua National Coalition for Liberation (WPNCL) in June, 2013. However, this submission triggered disputes within the FPM, considering that other organizations felt more entitled to submit such an application to the MSG. This eventually led the MSG to reject the application, due to the consideration that having an official organization is the main requirement for joining the MSG (O’Neill, 2014).

The above condition ultimately led FPM leaders to establish an official organization in December 2014 to represent their voice, known as The United Liberation Movement for West Papua (ULMWP). In 2015, after the establishment of this organization, the membership application to the MSG was accepted and they became an Observer Member in June, 2015. This finally triggered a lot of support from Melanesian countries, which could be seen later in some of the attitudes of leaders and civil society in those countries.

Support from Melanesian Countries in the MSG to the Free Papua Movement

The FPM's attempts to seek support from countries with similar racial composition ultimately achieved their goals, i.e. they received a lot of support from Vanuatu. This indicates that the Melanesian race in the South Pacific region view Indonesia as a common enemy. Vanuatu, in particular, uses the issues of human rights violations in Papua in the pre-reform era as a major concern to corner Indonesia in international forums.

Other support for the FPM comes from church forums in the Solomon Islands, through Peter Houhou, the Deputy General of the Dariss Anglican Archdiocese. He asserts: "We in the Solomon Islands have heard the cries of the people of West Papua and we commit to advocating their inherent right to gainful political self-determination and true freedom" (SICA supports freedom for West Papua people, 2014).

Furthermore, Nauru also officially declared their support for the FPM through a speech delivered at the Pacific Islands Forum Summit (KTT PIF) in 2000 in Tarawa, 
Kiribati. The President of Nauru himself, Bernard Dowiyogo, delivered a speech on September 7, 2000, at the United Nations Millennium Summit arguing that Indonesia is indeed a colonial country in Papua. Tuvalu became the next country to give support to the FPM, despite its limited capacity, in the form of financial backing (Wardhani, 2015a).

Such support as outlined above eventually triggered Indonesia to react, by striving to join the MSG in order to prevent further support being given by Melanesian countries to the Free Papua Movement.

\section{Indonesian Foreign Policies in the Melanesian Region}

After the emergence of various forms of support from Melanesian countries for the FPM, the initial attempt of the Indonesian government to prevent this was by improving the image of Indonesia, which Melanesian countries deem to be a country with a record of massive human rights crimes, especially against the people of Papua.

This attempt was made by joining the Melanesian Spearhead Group, despite the membership application submitted by the FPM to the organization. Indonesia submitted its membership application in 2010, although this received strong opposition from Vanuatu. However, in 2011 Indonesia was finally accepted and became an Observer Member. In this regard, Indonesia was supported by Fiji and Papua New Guinea.

The status of Observer Member enables Indonesia to become an observer of all activities in the Melanesian Spearhead Group. Indonesia still does not have the same rights and obligations as other member countries, such as in the case of voting (the Ministry of Foreign Affairs of the Republic of Indonesia, 2017).

After becoming an Observer Member, Indonesia invited MSG member countries to visit Papua and directly observe the actual situation. After this visit, the MSG started to perceive Papua as one of the Indonesian provinces whose development was very good, and even better than that of other MSG member countries (Azizian, Cramer, 2015).

After the visit, Indonesia advanced to the status of Associate Member in 2015. As stated by the Director of the Directorate General of Asia-Pacific and Africa at the Ministry of Foreign Affairs of the Republic of Indonesia, both active participation and intensive lobbying of Indonesian delegations, consisting of representatives from five provinces with Melanesian cultures (North Maluku, Maluku, East Nusa Tenggara, Papua, and West Papua) has successfully allowed Indonesia to become an Associate Member in the MSG (Percaya, 2016).

Since becoming an Associate Member, Indonesia's bargaining power in the MSG has gradually been increasing, since Indonesia can propose requirements and actively participate in every MSG activity. This essentially means that Indonesia can monitor the direction of MSG policies in the future, so that Indonesia can readily prepare various policy formulas in case MSG policies are counter to the national interest.

Generally, Indonesia's interest in joining the Melanesian Spearhead Group has finally been realized, as stated by the Director of the Directorate General of Asia-Pacific and Africa at the Ministry of Foreign Affairs in the interview, where he said that the acceptance of Indonesia as an Associate Member and the rejection of the FPM's goal to 
become a Permanent Member of the MSG shows that Indonesia's interest in maintaining national sovereignty has been achieved (Percaya, 2016).

\section{Discussion and conclusion}

The Indonesian foreign policy of joining the Melanesian Spearhead Group cannot be separated from the gradually intensifying activities of the Free Papua Movement in Papua, which potentially disturb national stability and sovereignty. On the other hand, Indonesia's decision to become a member of the MSG cannot be detached from the support given by Melanesian countries to the FPS in Papua.

In regard to this support, the best decision that can be taken by Indonesia is to approach those countries, even if the organization does not ensure such benefits as the ASEAN, for instance. However, despite the organization's economic insignificance, membership of the MSG can make it easier for Indonesia to take part (or influence) any policies issued by the MSG, by providing financial support to member countries. This surely will have a positive impact on Indonesia's image in the South Pacific region, especially in Melanesia.

Finally, it can be concluded that Indonesia has successfully protected or maintained its national sovereignty from the aggressive manoeuvers of separatist movements, such as the Free Papua Movement. This is evidenced by the rejection of the ULMWP's proposal to make it a permanent member in the Melanesian Spearhead Group. Therefore, it can be said that the MSG acknowledges Indonesia as its member, rather than the ULMWP.

\section{Bibliography}

Azizian R., Cramer C. (2015), Regionalism, Security \& Cooperation in Oceania, Asia Pacific Center for Security Studies, Port Vila.

Brown C., Kirsten A. (2005), Understanding International Relations, Third edit., Palgrave Macmillan, New York.

Hamid Z. (1996), Sistem Politik Pasifik Selatan, Cet. I, Pustaka Jaya, Jakarta.

Harris S. V, Brown C. (1985), Indonesia, New Guinea and Australia: The Irian Jaya Problem of 1984, "Australia-Asia Papers", no. 29.

Horowitz D. L. (1981), Patterns of Ethnic Separatism, "Comparative Studies in Society and History", no. 23 (2), pp. 165-195.

Kementerian Luar Negeri Indonesia (2017), Melanesian Spearhead Group (MSG), https://www.kemlu. go.id/id/kebijakan/kerjasama-regional/Pages/MSG.aspx.

Lita K. (2017), OPM Klaim Tanggung Jawab Penembakan Anggota Brimob Papua, http://regional. liputan6.com/read/3163407/opm-klaim-tanggung-jawab-penembakan-anggota-brimob-papua.

O’Neill P. (2014), MSG opens door for Papua membership, "Solomon Star”, Port Moresby, July 2, http:// www.solomonstarnews.com/index.php/component/content/article/147-news1/regional/2804msg-opens-door-for-papua-membership.

Percaya D. (2016), Organisasi Papua Merdeka Gagal Jadi Anggota Penuh MSG, Sekretariat Kabinet Republik Indonesia, Jakarta, http://setkab.go.id/organisasi-papua-merdeka-gagal-jadi-anggotapenuh-msg/. 
Raweyai T. Y., Suprantio H. (2002), Mengapa Papua Ingin Merdeka, Presidium Dewan Papua, Papua. Rosenau J. N. (1974), Comparing Foreign Policy: Theories, Findings and Methods, Sage Publications, New York.

SICA supports freedom for West Papua people (2014), http://www.solomonstarnews.com/index.php/ features/religion/item/2474-sica-supports-freedom-for-west-papua-people, November 18, 2017.

Tebay N. (2005), West Papua: The Struggle for Peace and Justice, Catholic Institute of International Relations, London.

Wardhani B. L. S. W. (2015a), Kajian Asia Pasifik Politik Regionalisme dan Perlindungan Manusia di Pasifik Selatan Menghadapi Kepentingan Negara Besar dan Kejahatan Transnasional, Intrans Publishing, Malang.

Wardhani B. L. S. W. (2015b), Quo Vadis Melanesian Spearhead Group?, "Global Strategies”, no. 9 (2), pp. 190-206.

\section{Międzyrządowa organizacja państw melanezyjskich (Melanesian Spearhead Group) a interes Indonezji}

\section{Streszczenie}

Artykuł przedstawia analizę jakościową korzyści, jakie upatruje Indonezja w członkostwie w międzyrządowej organizacji państw melanezyjskich (Melanesian Spearhead Group). Na podstawie pogłębionego wywiadu, przeprowadzonego z Dyrektorem Departamentu Azji, Państw Pacyfiku i Afryki w Ministerstwie Spraw Zagranicznych Republiki Indonezji, otrzymano aktualne dane, potwierdzone następnie literaturą przedmiotu. W rezultacie stwierdzono, że zasadniczym celem indonezyjskich starań o wstąpienie do MSG (międzyrządowej organizacji państw melanezyjskich) było utrzymanie wewnętrznej stabilizacji, co w tym kontekście odnosi się do wygaszenia działalności wciąż aktywnych w Indonezji ruchów separatystycznych, takich jak FPM (Ruch Wolnej Papui), otwarcie wspieranych przez państwa melanezyjskie, z którymi łączy je pochodzenie rasowe. Zabiegając o zachowanie suwerenności państwa, Indonezja pod rządami Prezydenta Joko Widodo, próbuje wstąpić do grupy MSG, aby zapobiec dalszemu wspieraniu grup separatystycznych przez tę międzyrządową organizację państw melanezyjskich, której działania mogą z punktu widzenia Indonezji zachwiać jednością Republiki Indonezji.

Słowa kluczowe: interes Indonezji, międzyrządowa organizacja państw melanezyjskich (Melanesian Spearhead Group), separatystyczny 